\title{
Is there an Indication of Financial Statement Fraud as a result of the Ore Export Policy?
}

\author{
Retno Widiastuti, Zainal Abdul Haris, Erlin Melani
}

\begin{abstract}
Regulations regarding the export policy of ore in Indonesia have undergone several changes over a relatively short period of time. The application of these regulations is predicted to have an impact on financial performance. Under these conditions managers often face pressure to carry out financial statements fraud when financial stability is threatened by economy, industry, and the situation of the operating entity. This study aims to detect the possibility of financial statements fraud. The research population was totally 173 companies data in the mining sector which were listed on the Indonesia Stock Exchange during 2014-2017. The research sample was selected by purposive sampling criteria and selected 101 companies data. The data collection method used is documentation. Data analysis is the Beneish M-Score calculation model. The results showed that the ore export ban did indeed affect the company's financial performance. Many companies in the sector cannot make sales transactions because of the policy. As a result, many companies in the sector reported losses in the current year. This condition certainly greatly affects the company's financial performance. This is also supported by the results of the Beneish M-Score calculation which shows that all research objects are indicated to manipulate their financial statements.
\end{abstract}

Keywords: financial performance, financial statement fraud

\section{INTRODUCTION}

Regulations regarding the export of raw minerals (ore) have undergone several changes over a relatively short period of time. The regulation in the spotlight is the enactment of the Law no. 4/2009 concerning Minerals and Coal [6]. This law was passed to regulate mineral and coal mining products, which prohibited the export of raw materials in January 2014. This law mandates the construction of smelters thus domestic mining production can be processed before being exported. The purpose of this Law is very noble, namely that Indonesia can feel the added value of mining products, boost gross domestic product, and absorb labor.This law also contains 2 main policies, namely the government is consistent in stopping raw mineral exports and the government is encouraging domestic processing and refining of minerals. However, in contrast to the initial

Revised Manuscript Received on September 22, 2019.

Retno Widiastuti, Accounting Departement, State Polytechnic of Malang, Malang, Indonesia.

Zainal Abdul Haris, Accounting Departement, State Polytechnic of Malang, Malang, Indonesia.

Erlin Melani, Accounting Departement, State Polytechnic of Malang, Malang, Indonesia. expectations, post-determination of this law mining exploitation actually jumped sharply. Many mining companies compete to mine as much as possible before the Law is effectively implemented. As a result, production of a number of mining commodities surged. Nationally there are several types of ore and mineral ore whose realization has increased massively in the last three years, including nickel ore exports increasing by $800 \%$, iron ore increasing by $700 \%$, and bauxite ore increasing by $500 \%$ [5]. The ore export ban which began in 2014 is considered to be deadly to mining and industry [4]. This condition is predicted to also have an impact on the performance of the mining industry as a whole, especially financial performance.

But in early January 2017, the government issued a new regulation which in principle opened the tap for export of several raw mineral commodities (ore) on January 11, 2017, which was previously closed on January 11, 2014. The regulation is Government Regulation Number 1 of 2017 concerning the fourth amendment to Government Regulation No. 23 of 2010 concerning the implementation of mineral and coal mining business activities. As a derivative of Government Regulation No. 1, the government also issued two Ministerial Regulations on Energy and Mineral Resources as instructions for implementing the Government Regulation. The first Ministerial Regulations of Energy and Mineral Resources is number 5 of 2017 concerning increasing mineral value added for mineral processing and refining activities in the country. The second Ministerial Regulations is number 6 of 2017 concerning the procedures and requirements for giving recommendations on the sale of minerals out of the country resulting from processing and purification.

This new regulation received a lot of criticism and even obtained a lawsuit for a material test. This new regulation is considered as a step back. Because, not only concentrates being export biases, but reopen the export taps of some of the raw mineral commodities that were previously closed on January 11, 2014. This new regulation is also considered to indicate inconsistency in the government in implementing mineral mining policies with processing and refining in domestic.

This situation attracted the attention of the researcher to further examine the impact of applying these regulations on financial performance of companies affected by the regulation, namely in the mining sub-sector. Poor financial performance will trigger bankruptcy. Under these conditions managers often 
face pressure to carry out financial statements of fraud when financial stability is threatened by the state of the economy, industry, and the situation of the operating entity. Financial stability is a condition that describes the condition of financial instability of the company [9]. This research refers to the research by Tiffani and Marfuah (2015). The difference between this research and the previous research is the object and the year of observation. This research was motivated to prove and observe the company's financial performance affected by these regulations, whether managers have the potential to conduct financial statement fraud due to inconsistent regulations. Based on this, this study aims to examine the indication of fraud due to inconsistency in the regulation of ore export regulations for companies in the mining sub-sector.

\section{LITERATURE REVIEW}

\section{A. Mining Product Export Policy}

Mines and minerals are non-renewable natural resources that are controlled by the state and their use is for the greatest prosperity of the people. Related to this, the government has continued to make efforts to encourage business people to continue to improve themselves and make breakthroughs so that they can boost the added value of Indonesian mines and minerals to a position that can prosper the people and determine the world trade in mines and minerals. The good intentions of the government in its efforts to encourage business actors are contained in Law No. 4 of 2009 concerning Mineral and Coal Mining. In principle this law regulates mineral and coal products, which prohibit the export of raw materials since January 2014. This law mandates the construction of smelters thus domestic mining production can be processed before being exported [5]. Smelter is a mineral processing and refining facility.

Law Number 4 of 2009 concerning Mineral and Coal Mining was formed to replace Law Number 11 of 1967 concerning the Basic Provisions of Mining which were deemed incapable of meeting national and international developments related to Mining.

The purpose of this law is for Indonesia to feel the added value of mining products, boost gross domestic product, and absorb labor. In contrast to the initial expectations, after the enactment of this law mining exploitation jumped sharply. Mine owners compete to mine as much as possible before being banned. As a result, production of a number of mining commodities surged. During the last three years after Law No. 4 In 2009, nationally there were several types of ore and mineral ore whose realization has increased massively, including nickel ore exports increasing by $800 \%$, iron ore increasing by $700 \%$, and bauxite ore increasing by $500 \%$ [5].

Recently the government has set Minister Regulation No. 5 of 2017, in force on 1 January 2017. The new regulation is to reopen the ban on exports of some commodities raw minerals (ore) which previously closed on January 11, 2014.

After the end of concentrate export relaxation, as of 11 January 2017, the government issued Government Regulation Number 1 of 2017, Energy and Mineral Resources Ministerial Regulation Number 5 of 2017, and Energy and Mineral Resources Ministerial Regulation Number 6 of 2017 [1]. Concentrate is a mineral that has been processed but has not reached the purification stage.
Some of the main things set out in ESDM Regulation 5/2017, are:

1. There is a list of minerals that can be sold abroad.

2. Open opportunities for export of nickel ore with levels below $1.7 \%$ (low levels) and washed bauxite with $\mathrm{A} 12 \mathrm{O} 3$ levels of more than $42 \%$ which are not absorbed by domestic smelters.

3. Most of the smelters in Indonesia absorb high grade nickel, thus low grade nickel and bauxite with A12O3 levels above $42 \%$ are wasted, so it will be better if exported.

4. The government requires smelters to absorb low grade nickel up to $30 \%$ of smelter capacity. The government has continued to encourage the two commodities to be purified domestically. That is, a minimum of $30 \%$ must be absorbed.

5. Low-grade nickel ore and bauxite export licenses are only given to mining companies that have built smelters. The construction of the smelter is evaluated continuously every 6 months. If the construction of the smelter is not progressing, the export permit will be revoked immediately.

6. The Mining Business Permit holder is given 5 years to complete the smelter.

7. The amount of nickel ore and bauxite that may be exported is limited according to the capacity of the smelter built and the amount of reserves in the mining area.

8. Exports of these two types of raw minerals are subject to export duty of up to $10 \%$. If the mining company does not immediately carry out purification, they will be very burdened.

So in the regulation the government argued that it did not take a step back. But on the contrary, the reopening of certain raw mineral exports was carried out to push back the construction of smelters that had not been implemented properly. However, this new rule has been widely criticized, some have considered the new policy as a step back. Even to get a lawsuit for a material test. Because, not only concentrates can be exported, the new rules reopen the export of some raw mineral commodities (ore) which were closed on January 11, 2014.

\section{B. Financial Distress}

Financial distress occurs before bankruptcy is actually experienced by the company. Financial distress is the stage of the decline in financial conditions that occur before the occurrence of bankruptcy or liquidation. Financial distress is used to mean severe liquidity problems that cannot be resolved without a sizable rescaling of the entity's operations or structure. Thus, financial distress is a situation where the company's operating cash flow is insufficient to pay off its current liabilities (such as trade payables or interest expenses) and the company is forced to take corrective action. Financial difficulties are very severe liquidity problems and cannot be solved without changes in the size of the company's operations or structure. Financial distress information can be used as an early warning of bankruptcy thus management can take action quickly to prevent problems before bankruptcy occurs. This financial distress can be seen from the situation where the company is not

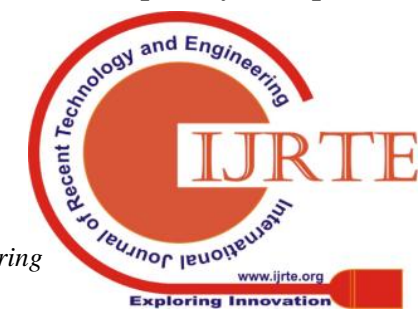


optimal in generating profits or companies tend to experience a deficit. Bankruptcy can be interpreted as a failure of the company in carrying out the company's operations to obtain profits.

Company liquidation, company closure, or insolvency, is another term for bankruptcy. Bankruptcy is financial failure and economic failure. Financial failure is a situation where a company loses money or company income is unable to cover its own costs. That is, the present value of the cash flow is actually smaller than the liability, it can also be interpreted that profit is smaller than working capital. Failure occurs when the actual cash flow of the company is far below the expected cash flow. Financial failure may be defined as the level of income from the investment is smaller than the cost of the company's capital. Financial failure can be interpreted as an insolvency that distinguishes between basic cash flows and shares. Insolvency on the basis of cash flow are two forms, namely technical insolvency and insolvency in terms of bankruptcy. Engineering insolvency is a condition where a company is considered unable to fulfill its obligations at maturity, even though the total assets exceed the total debt. Insolvency occurs when a company fails to fulfill one or more conditions in the terms of its debt. These provisions can be in the form of a ratio of current assets to established current liabilities or total net assets to the total assets required. Engineering insolvency also occurs when cash flows are insufficient to meet the repayment of the loan principal at a certain date. Insolvency in the sense of bankruptcy is defined as negative net worth in the statement of financial position or the present value of expected cash flows, smaller than liabilities. Bankruptcy is a condition of a company failing or unable to fulfill its obligations to creditors and the company experiences shortages and insufficient funds to run or continue its business thus the economic goals to be achieved by the company cannot be achieved. The economic goal that the company wants to achieve is profit, because the profits obtained by the company can be used to repay loans, finance company operations, fulfill other obligations, and prosper shareholders.

\section{Financial Statement Fraud}

The AICPA defines fraudulent financial statements as intentional, misstatements or omissions of material facts, or misleading accounting data and, if considered with all the information that has been made, will cause the reader to change his judgment or decision. In the ACFE itself fraudulent financial statements are divided into two things, namely, fraud in preparing financial statements consisting of assets/revenue overstatements and assets/revenue understatements and fraud in preparing non-financial reports [2].

Fraud compiling financial statements is an action taken by an official or executive of a company to cover up actual financial conditions by conducting financial engineering in the presentation of financial statements to obtain profits or may be analogous to the term window dressing [2]. Fraud in preparing financial statements can be triggered by the condition of the financial stability of an entity.

Financial stability is a picture of a company's financial condition be it stable or not. Management will always try to ensure that a company's financial stability always looks good by carrying out various ways and strategies. This creates a distinctive pressure for every management, especially when facing a situation where the company's financial condition is being threatened that management is compelled to commit fraud in its financial statements. When financial stability is threatened by the state of the economy, industry, and the situation of the operating entity, managers face pressure to carry out financial statement fraud [2]

Financial statement fraud can be explained using fraud triangle theory. Fraud triange theory consists of the connection among financial stability, financial targets, and financial effectiveness. Some research topic has been done based on that theory, such as Tiffani and Marfuah (2009) and Manurung and Hadian (2013).

\section{Methodology}

\section{A. Population, Samples, Sampling Techniques, and Data Collection Methods}

The population in this study is all companies in the mining sector that are listed on the Indonesia Stock Exchange (IDX) during the period 2014 - 2018. The sampling technique was purposive sampling, with the following criteria:

1. The company is listed on the Indonesia Stock Exchange in succession during the period of observation.

2. The company is not in the oil and gas mining sub-sector group.

3. This is because in Article 1 of Law No. 4 of 2009, concerning Mineral and Coal Mining, oil and gas mining, is excluded from the regulation.

4. The company presents complete financial statements during the period of observation.

Companies in the mining sector that are listed on the Indonesia Stock Exchange (IDX), including sub-sectors (Indonesia Stock Exchange, 2017:31) :

1. Coal Mining

2. Crude Petroleum \& Natural Gas Production

3. Metal and Mineral Mining

4. Land/Stone Quarrying

5. Others

The results of research sampling are in table 1, as follows:

Table 1. Purposive Sampling Results

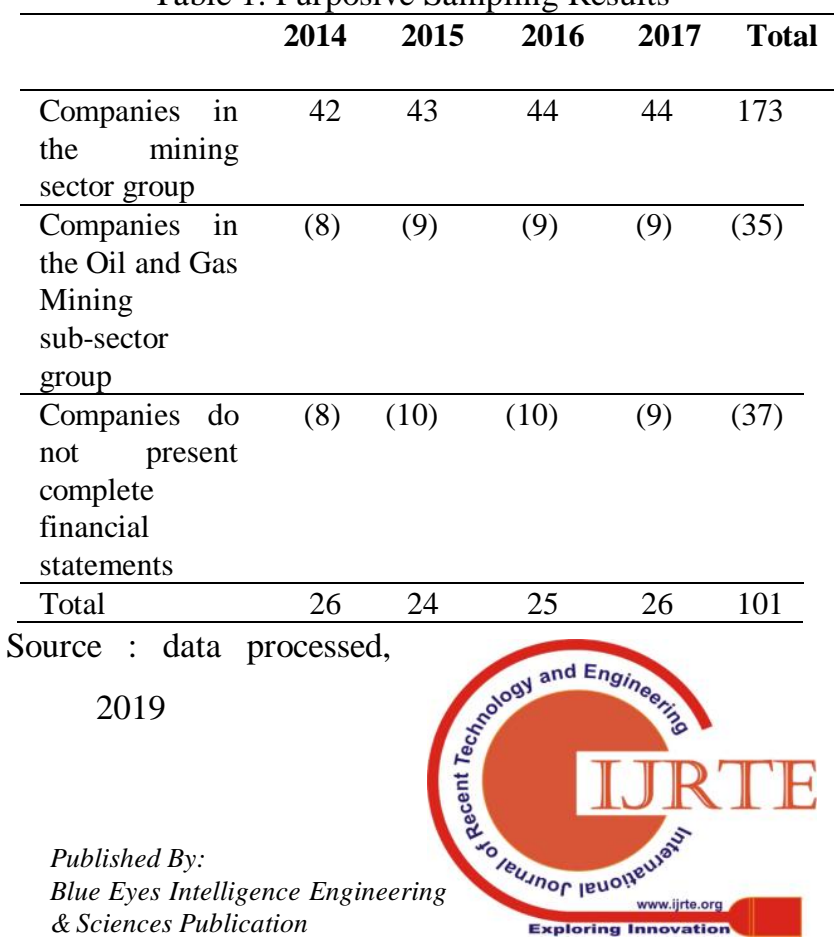


The data collection method used in this study was documentation. The data used was archival data, namely secondary data obtained from various existing publications. The data needed in this study came from the 2014-2019 financial statements obtained from the site www.idx.co.id.

\section{B. Research Variables and Definition of Variable Operational}

The following describes the research variables and operational definitions of the variables used in this study. The research variables used in this study were financial statement fraud and ore export policies. Following are the explanations of each.

\section{Financial statement fraud}

Fraud is a deception or mistake made by a person or entity who knew that this mistake may result in some benefits that are not good to individuals or [9]. So financial statemant fraud is an act of deception or error in the financial statements of an entity, which can result in benefits that are not good to other parties.

How to detect whether a company has manipulated (fraud), using the calculation model Beneish M-Score [9]. Below is formula and list of financial ratio for calculating Beneish M-Score:

$$
\begin{aligned}
\text { M-Score }= & -4,84+0,920 \text { DSRI }+0,528 \mathrm{GMI}+0,404 \mathrm{AQI} \\
& +0,892 \mathrm{SGI}+0,115 \mathrm{DEPI}-0,172 \mathrm{SGAI}- \\
& 0,327 \mathrm{LVGI}+4,697 \text { TATA }
\end{aligned}
$$

Table 2. Financial Ratio for Calculating Beneish M-Score
2. Ore export policy.

Regulations regarding the export of raw minerals (ore) have undergone several changes over a relatively short period of time. Following is the change in policy: a. Law no. 4/2009 concerning Minerals and Coal (Minerba). This law was passed to regulate the removal of mineral and coal products, which banned the export of raw materials in January 2014.

b. In early January 2017, the government issued Government Regulation Number 1 of 2017 (PP 1/2017), ESDM Ministerial Regulation Number 5 of 2017 (ESDM Ministerial Regulation 5/2017), and ESDM Ministerial Regulation Number 6 of 2017 (ESDM Ministerial Regulation 6/2017) . This new regulation principally opens up the export of several ore minerals on 11 January 2017.

Figure 1. Time Period of Ore Export Policy

\begin{tabular}{|l|l|}
\hline 2014 & 2017 \\
\hline Export ban period & Reopening period of the export ban \\
\hline
\end{tabular}

\section{Data Analysis Technique}

Data analysis in this study was carried out in two stages, namely :

1. The first step is to calculate the Beneish M-score using financial ratios.

2 . The second stage is to determine indications of fraud in the company's financial statements in the mining sector.

3. The third stage, comparing indications of fraud in the export ban period with the reopening period of the export ban.

\section{RESUlts AND FINDINGS}

The results of data processing for companies in the

\begin{tabular}{|c|c|c|}
\hline 4 & $\begin{array}{l}\text { Sales Growth } \\
\text { Index (SGI) }\end{array}$ & $S G I=\frac{\text { Salest }}{\text { Sales } t-1}$ \\
\hline 5 & $\begin{array}{l}\text { Depreciation } \\
\text { Index (DEPI) }\end{array}$ & $D E P I=\frac{[(\text { Depreciation } t-1 /(\text { PPE } t-1+\text { Depreciation } t-1)]}{[(\text { Depreciation } t /(P P E t+\text { Depreciation } t)]}$ \\
\hline 6 & $\begin{array}{l}\text { Sales General } \\
\text { and } \\
\text { Administrativ } \\
\text { e Expenses } \\
\text { (SGAI) }\end{array}$ & $S G A I=\frac{(\text { SG\&A Expenset } / \text { Sales } t)}{(\text { SG\&A Expense } t-1 / \text { Sales } t-1)}$ \\
\hline 7 & $\begin{array}{l}\text { Leverage } \\
\text { Index (LVGI) }\end{array}$ & $L V G I=\frac{[(\text { Current Liabilitiest t Long Term Debt } t) / \text { Total Assetst }]}{[(\text { Current Liabilitiest }-1+\text { LongTrmm Debtt }-1) / \text { Total Assets } t-1]}$ \\
\hline 8 & $\begin{array}{l}\text { Total Accruals } \\
\text { to Total } \\
\text { Assets } \\
\text { (TATA) } \\
\end{array}$ & TATA $=\frac{\text { (Net Income from Continuing Operationst }- \text { Cash Flows from Operations }}{\text { Totalassets t }}$ \\
\hline
\end{tabular}

3 Asset Quality $A Q I=\frac{(\text { TAt }-(\text { CAt }+P P E t) / T A t)}{(T A t-1-(C A t-1+P P E t-1) / T A t-1)}$ mining sector during the observation period are as follows:

Table 3. Results of Financial Ratios Calculation

\begin{tabular}{rlrrrr}
\hline No & $\begin{array}{c}\text { Financial } \\
\text { Ratio }\end{array}$ & $\mathbf{2 0 1 4}$ & $\mathbf{2 0 1 5}$ & $\mathbf{2 0 1 6}$ & $\mathbf{2 0 1 7}$ \\
\hline 1 & DSRI & 1,455227 & 1,022774 & 2,024268 & 1,092956 \\
\hline 2 & GMI & 0,692726 & 3,237228 & 3,182529 & 1,076021 \\
\hline 3 & AQI & 1,495731 & 0,691471 & 1,082746 & 0,953193 \\
\hline 4 & SGI & 0,95305 & 1,02248 & 2,341651 & 1,329413 \\
\hline 5 & DEPI & 0,92368 & 2,907842 & 1,188271 & 1,05067 \\
\hline 6 & SGAI & 1,350352 & 1,253271 & 1,576313 & 0,914305 \\
\hline 7 & LVGI & 1,038228 & 0,984231 & 0,949198 & 1,041607 \\
\hline 8 & TATA & $-0,02954$ & $-0,05728$ & $-0,06247$ & $-0,03372$ \\
\hline \multicolumn{7}{l}{ Source: data processed, 2019} \\
\end{tabular}

Based on the calculation of the financial ratios, the next calculation phase was carried out, namely calculating the Beneish M-Score. The Beneish M-Score formula and the calculation results are as follows:

The company is indicated to perform manipulation (fraud), if the Beneish M-score is greater than -2.22, and vice versa if the score is smaller. 
M-Score $=-4,84+0,920 \mathrm{DSRI}+0,528 \mathrm{GMI}+0,404 \mathrm{AQI}+$ 0,892 SGI + 0, 115 DEPI $-0,172$ SGAI $-0,327$ LVGI $+4,697$ TATA

Table 4. Results of Beneish M-Score Calculation

\begin{tabular}{rrr}
\hline No & Year & \multicolumn{1}{c}{$\begin{array}{c}\text { Beneish } \\
\text { M-Score }\end{array}$} \\
\hline 1 & 2014 & 7,219 \\
\hline 2 & 2015 & 8,201 \\
\hline 3 & 2016 & 10,171 \\
\hline 4 & 2017 & 7,449 \\
\hline
\end{tabular}

Source: data processed, 2019

The company is indicated to perform manipulation (fraud), if the Beneish M-score is greater than -2.22, and vice versa if the score is smaller. The results showed that in 2014-2017 all sample companies manipulated their financial statements. Because the Beneish M-Score results showed a number greater than -2.22 . However, even though all indicated cheating, the score results also vary.

The large diversity of the Beneish M-Score, which can be observed at the end of 2016, the third year of regulation implementation, the score is 10,171 . It can be said that the influence of implementing regulations has affected the company too much. This shows that the greater the manipulation of financial statements. It also can be observed that the score began to increase since 2014. It declined on 2017 , on the year of reopening period of the export ban. This can be said that during this period the manipulation of financial statements diminished. The highest score not occur in the beginning of the implementation of the ore export ban policy, but it went up from year to year.

\section{Conclusion}

This study aims to examine the indication of fraud due to the inconsistency of the ore export ban policy for companies in the mining sub-sector. The results show that the ore export ban did indeed affect the company's financial performance. Many companies in the sector cannot make sales transactions because of the policy. As a result, many companies in the sector reported losses in the current year. This condition certainly greatly affects the company's financial performance. This is also supported by the results of the Beneish M-Score calculation which shows that all research objects are indicated to manipulate their financial statements.

The limitations of this study are in the period of observation after the export ban policy was stopped. Observation was only carried out a year after the export tap was reopened, which was in 2017. This was due to the company's financial report in 2018 which had not been published when the data was processed. Future research should add to the period of observation. It is also used to observe the Beneish M-score value, which should decrease further, or in other words the manipulation of financial statements decreases.

\section{REFERENCES}

1. Agustinus, M. (2017).Ekspor Mineral Mentah Kembali Dibuka, Ini Penjelasan ESDM. Available: https://finance.detik. Retrieved on 22 Oktober 2017.

2. Aprillia, O. Cicilia, dan R. P. Sergius. (2015). The Effectiveness of Fraud Triangle on Detecting Fraudulent Financial Statement: Using Beneish Model and The Case of Special Companies. Jurnal Riset Akuntansi dan Keuangan, 3(3): 786-800.

3. Beneish,M D. (1997). Detecting GAAP violation: implications for assessing earnings management among firms with extreme financial performance. Journal of Accounting and Public Policy, 16 (3): 271-309

4. Larangan Ekspor Total Bijih Mineral, Rugikan Industri. Available : http://kemenperin.go.id/artikel

5. Kementrian Perdagangan RI. (2012). Analisis Dampak Kebijakan Pelarangan Ekspor Raw Material Tambang dan Mineral.

6. Manurung, D. T. H dan N. Hadian. (2013). Detection fraud of Financial Statement with Fraud Triangle. Proceeding of $23^{\text {rd }}$ International Business Research Conference, Melbourne.

7. Pemerintah Republik Indonesia. (2009). Undang-Undang no 4/2009. Pertambangan Mineral dan Batubara.

8. Skousen, C.J.,R.K.R. Smith, and C.J. Wright. 2009. Detecting and Predicting Financial Statement Fraud: The Effectiveness Of The Fraud Triangle and SAS No. 99. Corporate Governance And Firm Performance (Advance In Financial Economics), 13: 53-81.

9. Tiffani, L dan Marfuah. (2015). Deteksi Financial Statement Fraud dengan Analisis Fraud Triangle pada Perusahaan Manufaktur yang Terdaftar di Bursa Efek Indonesia. Journal Akuntansi dan Auditing Indonesia, 19(2): 112-125.

10. Indonesia Stock Exchange. 2017. IDX Statistics 2017

\section{AUTHORS PROFILE}

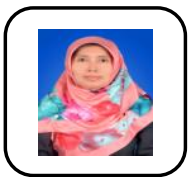

Retno Widiastuti, SE., MSA., Ak., CA, is a lecture in Accounting Department, State Polytechnic of Malang, Indonesia. She is also an auditor at public accounting firm. She actively writes and publishes them in local and international proceedings and journals.

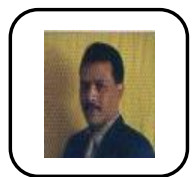

Zainal Abdul Haris, SE., MSi., Ak., CA , is a lecture in Accounting Department, State Polytechnic of Malang, Indonesia. He actively writes and publishes them in local and international proceedings and journals.

Erlin Melani, SE., MSA., Ak., CA., CSRS., CSRA is is a lecture in Accounting Department, State Polytechnic of Malang, Indonesia. She actively writes and publishes them in local and international proceedings and journals. 